ond question is as positively auswered in these words: "When the gray matter is divided with very slight injury to the white substance, sensibility in the parts below the point of section is totally destroyed." And the answer to the third question is deduced from the answers to the first two. What can be more positive!

Again, Ranney, "Applied Anatomy of the Nervous System," p. 300, says, "The sensory fibres found in the posterior root (of the spinal cord) ascend in the column of Burdach for a short distance only, when they pass into the gray matter of the posterior half of the cord."

Other American authors are equally positive in stating that the sensory tract of the spinal cord is the gray matter, and almost certainly that portion of the gray substance near the central canal.

As students of medicine and seekers of truth, we have accepted this without mental reservation.

In opposition, however, to the foregoing, Byron Bramwell, of Edinburgh, in his recent work on the spinal cord, is positively contradictory.

By examining this work it will be found that Figs. 29 , $30,31,38,59$ and 61 , distinctly show the sensory tract of the cord to be the posterior white column, or the column of Burdach, and not the gray substance, according to Flint, Hammond, Rauney and others.

The explanatory text in Bramwell confirms the cuts in every instance. I am after the truth, if it is known. Who is right?

Dennison, $\mathrm{O}$.

\section{Shall The Journal be Removed to Washington?}

To the Editor:-I prefer Chicago.

Cleveland $O$.

WM. T. CORLET'T, M.D.

To the Editor:--I have waited until the present before expressing my opinion upon the action of the Trustees of THE JOURNAI, at their late meeting, advising that at the end of the present year, THu Journal should be permanently established in a central office at Washington. The only argument offered in favor of the change was by one of the new Trustees who stated that he voted for it because he was pledged to that course of action before his appointment.

Few know better than myself the events which led to the establishment of THE JOURNAL and its location in Chicago. It was but natural to expect that there would exist a rivalry between the leading centres of our great country for its possession, since it is easy to understand the power and influence which such a journal might exert if made the exponent of local interests. Fortunately for the Association and the Nation, the guardians of the interests of THE JOURNAL have thus far been enabled to hold in restraint all ulterior influences, and have treated the interests of the different sections of our country with impartial justice.

There can be no doubt that a very much better journal could have been furnished by the expenditure of a much larger sum of money, but no one can now question the wisdom of the Trustees and the self-sacrificing economic care of our first editor, Dr. Davis, in adopting the "pay as you go system."

In its rapid growth and development, our journal is now justly considered the peer of any of the great weeklies of the Eastern cities, and under wise and energetic control it should become the leading exponent of the best medical thought in America. With such a history and such a promise of future good, what gain is to be expected by a change of location to Washington?

Is it because Washington is the capital city and the centre of the political influences of our country? Some have felt that already the greatest danger to our Association and its journal lies in the fact that a political ele- ment has entered into its organization and is seeking control. If there is reason for apprehension in this direction, it would be a strong argument for its removal from Washington had it been established there instead of at Chicago.

Is it because Washington is a greater literary, medical, or educational centre than Chicago? We have all watched with amazement the wonderful growth of Chicago, until she has become the second great city of our country, and great as she is in wealth and commercial activity, those who know her best, know that she is lavishing her money upon libraries, art collections, universities, and schools of learning, until we in the East look with jealous eye at our fast departing preëminence. No city in the world has equalled her in growth and prosperity, and none give greater promise for the future.

As a center for ease of access, or for rapid distribution, Washington offers nothing in consideration. Whatever else may be said of medical journalism in common with every other publication, it must be considered as a busiiness enterprise. "Can it be made to pay?" was the doubtful question asked at the baptism of our journal. "What are the profits already?" is the query meeting every suggestion for improvenent, and "is it possible to defray the necessary expenditure?" The income of THE JourNaI, is depencient upon two factors, the subscription list and the advertising sheet. Can the Trustees show that in either respect the income is likely to be increased by its removal to Washington? The subscription list will depend, in a very large degree, upon the character of THE JOURNAL, and no one can doubt that its interest and value can at least be made equal in its present location to that of any other. I do not suppose that any one will advance the argument that it is really necessary to remove THE JOURNAL, to Washington in order to provide for it a competent editor.

It is equally clear that THE JourNaI, can be published as economically in Chicago as in any other of the great centres of our country.

When we take into consideration the legitimate income to be derived from the advertising department, it requires little proof for the demonstration that the larger the local centre from which a journal emanates, the greater is the value of that journal for advertisers. On this account our journal is especially fortunate in having its home in Chicago, and we cannot help thinking that it would be most unfortunate and detrimental to its interests to remove it to Washington.

Boston, New York, Philadelphia, Baltimore, Cincinnati, Louisville, Nashville, St. Louis, each have their medical weeklies dependent largely upon local interests. Remove our journal from Chicago and the field will be open for the establishment of another weekly medical journal dependent in a large degree for its support upon its legitimate advertising.

Let the business interests of our journal continue to be transacted upon strictly business principles; secure for its management the best talent to be obtained and trust the future for its greatly increased usefulness. When the time comes that our finances will warrant the expenditure of a large sum of money for buildings and the accessories for a large publication house, then, and not till then, let the Association discuss the question of an elaborate home. For the present, at least, our Trustees have more vital subjects demanding their attention in increasing the value of THE JOURNAL and making it the worthy repository for the best medical thought and science of the new world.

I 6 Boylston st., Boston, Mass., January 19, I89i.

To the Editor:-Let THE JOURNAL, remain in Chicago. It is certain that the place wherein it is published will largely impress its own character upon it. The fact that 